\title{
Perlindungan Hukum Terhadap Hak Pemegang Jaminan Gadai Saham
}

\author{
Annisa Oktaviananda Putri \\ Magister Kenotariatan Fakultas Hukum Universitas Islam Indonesia \\ Jln. Cik Di Tiro No. 1 Yogyakarta \\ annisaope@gmail.com
}

\begin{abstract}
This research contains the problem formulation as follow, first, what is the rationale behind the judge's consideration in deciding the share-mortgage case based on the Supreme Court Decision No. 240 PK/Pdt/2006 and the Supreme Court Decision No. 115 PK/Pdt/2007. Second, how the Supreme Court Decision No. 240 PK/Pdt/2006 and the Supreme Court Decision No. 115 PK/Pdt/2007 provide legal protection to the mortgaged share holders. This is a normative legal research with case and legislation approach. The results indicate that there are differences in the outcomes of the Supreme Court Decision No. 240 PK/Pdt/2006 and the Supreme Court decision No. 115 PK/Pdt /2007 in the substance of the similar case. Based on the Supreme Court No. 240 PK/Pdt/2006, the execution of share-mortgage by PT BFI Finance Indonesia Tbk is illegal, while in the Supreme Court Decision No. 115 PK/Pdt/2007 the execution by PT BFI Finance Indonesia Tbk is legal. The difference in the outcomes of the decisions in the substancially similar cases has created legal uncertainty over the protection of PT BFI Finance Indonesia Tbk's rights as a creditor as well as the mortgaged share holder.
\end{abstract}

Key Words: Legal protection; share-mortgage; security

\begin{abstract}
Abstrak
Penelitian ini memiliki rumusan masalah yaitu, pertama, apa yang menjadi dasar pertimbangan hakim dalam memutuskan perkara gadai saham berdasarkan Putusan Mahkamah Agung Nomor 240 PK/Pdt/2006 dan Putusan Mahkamah Agung Nomor 115 PK/Pdt/2007. Kedua, bagaimana Putusan Mahkamah Agung Nomor 240 PK/Pdt/2006 dan Putusan Mahkamah Agung Nomor 115 PK/Pdt/2007 memberikan perlindungan hukum kepada pemegang gadai saham. Jenis penelitian yang digunakan adalah penelitian hukum normatif dengan pendekatan kasus dan perundang-undangan. Hasil penelitian ini menunjukkan bahwa adanya perbedaan hasil Putusan Mahkamah Agung Nomor 240 PK/Pdt/2006 dan Putusan Mahkamah Agung Nomor 115 PK/Pdt/2007 dalam substansi perkara yang sama. Berdasarkan Putusan Mahkamah Agung Nomor 240 PK/Pdt/2006, eksekusi gadai saham yang dilakukan PT BFI Finance Indonesia Tbk adalah tidak sah demi hukum, sedangkan dalam Putusan Mahkamah Agung Nomor 115 PK/Pdt/2007 eksekusi yang dilakukan PT BFI Finance Indonesia Tbk adalah sah demi hukum. Adanya perbedaan hasil putusan tersebut dalam substansi perkara yang sama tersebut menimbulkan ketidakpastian hukum atas perlindungan hak PT BFI Finance Indonesia Tbk sebagai kreditur sekaligus pemegang jaminan gadai saham.
\end{abstract}

Kata-kata Kunci: Gadai saham; perlindungan hukum; jaminan 


\section{Pendahuluan}

Saham merupakan salah satu benda yang dapat dijaminkan untuk mendapatkan dana. Sebagaimana disebutkan dalam Pasal 60 ayat (1) UndangUndang Nomor 40 Tahun 2007 tentang Perseroan Terbatas (selanjutnya disebut "UUPT), saham merupakan benda bergerak sehingga memberikan hak atas saham tersebut kepada pemiliknya. Saham dapat dijadikan sebagai objek jaminan karena sifatnya sebagai benda yang memiliki nilai ekonomis dan memberikan hak kepemilikan atas suatu perseroan.

Istilah jaminan sendiri berasal dari kata zekerheid atau cautie, yang berarti kemampuan debitur untuk memenuhi atau melunasi perutangannya kepada kreditor, dimana dilakukan dengan menahan benda tertentu yang bernilai ekonomis sebagai tanggungan atas pinjaman atau utang yang diterma debitur terhadap krediturnya. ${ }^{1}$ Konsepsi jaminan secara umum dapat ditemukan dalam ketentuan Kitab Undang-Undang Hukum Perdata (selanjutnya disebut "KUHPerdata"). Pasal 1131 mengatur bahwa segala kebendaan debitur, baik yang bergerak maupun yang tidak bergerak, baik yang sudah ada maupun yang baru akan ada di kemudian hari, menjadi jaminan suatu segala perikatan pribadi debitur tersebut. Oleh karenanya, jaminan merupakan sarana untuk menjamin pemenuhan prestasi oleh debitur.

Pasal 60 ayat (2) UUPT mengatur bahwa saham dapat diagunkan dengan gadai atau fidusia. ${ }^{2}$ Gadai merupakan suatu hak jaminan kebendaan atas kebendaan bergerak tetentu milik debitur atau seseorang lain atas nama debitur untuk dijadikan sebagai jaminan pelunasan utang tertentu, yang memberikan hak untuk didahulukan (hak preferen) kepada pemegang hak gadai atas kreditur lainnya, setelah terlebih dahulu didahulukan dari biaya untuk lelang dan biaya menyelamatkan barang-barang gadai yang diambil dari hasil penjualan melalui pelelangan umum atas barang-barang yang digadaikan. ${ }^{3}$ Hak gadai lahir atau dianggap telah terjadi setelah terjadinya penyerahan kekuasaan fisik barang objek gadai kepada penerima gadai. Setiap gadai saham atau jaminan fidusia atas saham yang dilakukan berdasarkan Pasal 60 ayat (3) UUPT wajib dicatat dalam daftar pemegang saham dan daftar khusus.

Gadai merupakan hak yang bersifat accesoir (tambahan), sehingga keberadaanya tergantung pada perjanjian pokoknya. Dengan demikian,

\footnotetext{
${ }^{1}$ Rachmadi Usman, Hukum Jaminan Keperdataan, Cetakan Pertama, Sinar Grafika, Jakarta, 2008, hlm. 66.

2 Pasal 60 ayat (2) Undang-Undang Nomor 40 Tahun 2007 tentang Perseroan Terbatas: "Saham dapat diagunkan dengan gadai atau jaminan fidusia sepanjang tidak ditentukan lain dalam anggaran dasar".

${ }^{3}$ Rachmadi Usman, Op. Cit., hlm. 105.
} 
perjanjian gadai tidak bisa berdiri sendiri tanpa ada perjanjian pokoknya, dalam hal ini perjanjian utang-piutang. Perjanjian utang-piutang merupakan hubungan dimana ada kewajiban bagi debitur untuk melakukan prestasi dan hak atas prestasi dari kreditur. Apabila debitur tidak memenuhi prestasi yang diperjanjikan maka kreditur mempunyai hak untuk menuntut pemenuhan piutangnya terhadap harta kekayaan debitur yang dipakai sebagai jaminan.

Akan tetapi, pada praktek gadai saham, penerapan hak untuk menuntut pemenuhan prestasi debitur oleh kreditur mengalami berbagai permasalahan, seperti dalam kasus yang terjadi antara PT BFI Finance Indonesia Tbk dengan PT Aryaputra Teguharta dan PT Ongko Multicorpora. Pada kasus tersebut, PT Aryaputra Teguharta dan PT Ongko Multicorpora yang memiliki bagian saham di PT BFI Finance Indonesia Tbk melakukan perjanjian gadai saham dengan PT BFI Finance Indonesia Tbk. Permasalahan timbul ketika jatuh tempo perjanjian PT Aryaputra Teguharta dan PT Ongko Multicorpora belum menyelesaikan prestasi yang diperjanjikan. PT BFI Finance Indonesia Tbk pun menerapkan hak untuk pemenuhan prestasi debitur dengan mengeksekusi jaminan gadai saham tersebut. Namun kemudian PT Aryaputra Teguharta dan PT Ongko Multicorpora menggugat PT BFI Finance Indonesia Tbk karena dianggap dengan melakukan eksekusi gadai saham tersebut PT BFI Finance Indonesia Tbk telah melakukan perbuatan melawan hukum.

Kedua kasus tersebut sudah terdapat putusan pengadilan yang memiliki kekuatan hukum tetap yaitu Putusan Mahkamah Agung Nomor 240 PK/Pdt/2006 (antara PT Aryaputra Teguharta dengan PT BFI Finance Indonesia Tbk) dan Putusan Mahkamah Agung Nomor 115 PK/Pdt/2007 (antara PT Ongko Multicorpora dengan PT BFI Finance Indonesia Tbk). Meskipun sudah ada putusan pengadilan yang memiliki kekuatan hukum tetap, namun putusan tersebut masih menimbulkan permasalahan hukum. Hal tersebut dikarenakakan kedunya memiliki putusan yang berbanding terbalik antara putusan yang satu dengan yang lain, sedangkan kedua perkara tersebut memiliki substansi gugatan yang sama dan yang membedakan hanyala subjek penggugat. Putusan Mahkamah Agung Nomor 240 PK/Pdt/2006 menyatakan eksekusi gadai saham yang dilakukan oleh PT BFI Finance Indonesia Tbk atas saham milik PT Aryaputra Teguharta merupakan perbuatan melawan hukum sehingga tidak sah dan batal demi hukum. Sedangkan dalam Putusan Mahkamah Agung Nomor 115 PK/Pdt/2007, Majelis Hakim menyatakan bahwa eksekusi gadai saham yang dilakukan oleh PT BFI Finance Indonesia Tbk atas saham milik PT Ongko Multicorpora adalah tepat dan sah demi hukum. 


\section{Rumusan Masalah}

Berdasarkan uraian di atas, maka masalah yang dirumuskan dalam penelitian ini sebagai berikut. Pertama, apa yang menjadi dasar pertimbangan hukum hakim dalam memutuskan perkara gadai saham berdasarkan Putusan Mahkamah Agung Nomor 240 PK/Pdt/2006 dan Putusan Mahkamah Agung Nomor 115 PK/Pdt/2007, yang menyebabkan putusan berbeda? Kedua, bagaimana Putusan Mahkamah Agung Nomor 240 PK/Pdt/2006 dan Putusan Mahkamah Agung Nomor 115 PK/Pdt/2007 telah memberikan perlindungan hukum kepada penerima gadai saham?

\section{Tujuan Penelitian}

Penelitian ini beretujuan untuk mengkaji dasar pertimbangan hukum hakim dalam memutuskan perkara gadai saham berdasarkan Putusan Mahkamah Agung Nomor 240 PK/Pdt/2006 dan Putusan Mahkamah Agung Nomor 115 PK/Pdt/2007, yang menyebabkan putusan berbeda. Selain itu, penelitian ini juga bertujuan untuk menganalisis bagaimana Putusan Mahkamah Agung Nomor 240 PK/Pdt/2006 dan Putusan Mahkamah Agung Nomor 115 PK/Pdt/2007 memberikan perlindungan hukum kepada pemegang gadai saham.

\section{Metode Penelitian}

Penelitian ini menggunakan jenis penelitian hukum normatif, yaitu penelitian hukum dengan mengkonsepsikan hukum sebagai norma meliputi nilai-nilai, hukum positif dan putusan pengadilan. Metode pendekatan yang digunakan dalam penelitian ini adalah pendekatan kasus, pendekatan perundang-undangan dan pendekatan konseptual, yaitu menelaah kasus yang berkaitan dengan masalah yang dihadapi dan kemudian dikaji berlandaskan pada peraturan peraturan perundang-undangan yang berlaku dan konsepkonsep hukum.

Bahan hukum yang digunakan dalam penelitian ini adalah bahan hukum primer, yaitu bahan yang mempunyai kekuatan mengikat secara yuridis, seperti Kitab Undang-Undang Hukum Perdata, Undang-Undang Nomor 4 Tahun 1995 tentang Pasar Modal, Undang-Undang Nomor 40 Tahun 2007 tentang Perseroan Terbatas, serta bahan hukum sekunder yang terdiri dari dokumen, literatur, jurnal ilmiah, serta hasil penelitian terdahulu. Teknik pengumpulan data dilakukan dengan studi pustaka dan studi dokumen yang akan disusun dan dianalisis secara kualitatif, yaitu data dianalisis dan hasil analisis disajikan secara 
sistematis sesuai dengan permasalahan yang diteliti dengan menguraikan secara deskriptif hasil data yang diperoleh, serta akan dilakukan pengambilan kesimpulan.

\section{Hasil Penelitian dan Pembahasan}

Perbedaan Dasar Pertimbangan Hukum Hakim dalam Putusan Mahkamah Agung Nomor 240 PK/Pdt/2006 dan Putusan Mahkamah Agung Nomor 115 PK/Pdt/2007

PT Aryaputra Teguharta (selanjutnya disebut "PT APT") dan PT Ongko Multicorpora (selanjutnya disebut "PT OM") merupakan perusahaan yang tergabung dalam Ongko Group. PT APT dan PT OM sejak 1997 dan 1998 telah memperoleh fasilitas kredit berdasarkan perjanjian-perjanjian Domestic Resource Factory Agreement dan Financial Leasing Agreement dari PT BFI Finance Indonesia Tbk (dahulu PT Bunas Finance Indonesia) (selanjutnya disebut “PT BFI). PT BFI menerima jaminan yang diikat dengan hak gadai sebagai jaminan atas fasilitas yang diberikan tersebut, yaitu berupa saham PT APT sejumlah 111.804.732 lembar saham $^{4}$ dan saham PT OM sejumlah 98.388.180 lembar saham. ${ }^{5}$ Saham-saham yang dijaminkan tersebut merupakan saham-saham milik PT APT dan PT OM yang ada di PT BFI.

Perjanjian jaminan atas saham tersebut dituangkan dalam Pledges of Shares Agreement 1 Juni 1999 (selanjutnya disebut "Perjanjian Gadai Saham") yang ditandatangani oleh PT APT dan PT OM dengan PT BFI. Para pihak selanjutnya sepakat untuk menunjuk dan mengangkat The Chase Manhattan Bank cabang Jakarta selaku Depository Agent (agen penyimpan) atas saham-saham yang dijaminkan oleh PT APT dan PT OM, sebagaimana tertuang dalam Depository Agreement 1 Juni 1999. Setelah itu, PT BFI mengeluarkan surat pemberitahuan pada 10 Juni 1999 kepada PT Sirca Datapro Perdana selaku Biro Administrasi Efek untuk didaftarkan gadai saham-saham tersebut dalam Daftar Buku Saham PT BFI, dan telah dikonfirmasi pada 12 Juni 1999 bahwa gadai saham tersebut telah dicatat. Perjanjian gadai saham tersebut pernah diperpanjang, yaitu pada 22 Februari 2000, sehingga jatuh tempo gadai saham menjadi 1 Desember 2000,6 dan kemudian diperpanjang lagi pada 28 Nopember 2000 di mana jatuh tempo gadai saham manjadi 1 Desember $2001 .^{7}$

\footnotetext{
4 Putusan Mahkamah Agung Republik Indonesia pada tingkat Peninjauan Kembali dalam perkara PT Aryaputra Teguharta v. PT BFI Finance Indonesia Tbk., dke, Nomor 240 PK/Pdt/2006, hlm. 3.

5 Putusan Mahkamah Agung Republik Indonesia pada tingkat Peninjauan Kembali dalam perkara PT Ongko Multicorpora v. PT BFI Finance Indonesia Tbk., dke, Nomor 115 PK/Pdt/2007, hlm. 2.

6 Putusan Mahkamah Agung Republik Indonesia Nomor 240 PK/Pdt/2006, Loc. Cit.

${ }^{7}$ Ibid., hlm 19.
} 
PT BFI kemudian berencana untuk melakukan restrukturasi utang-utangnya dengan cara melakukan negoisasi dengan para krediturnya. Restrukturisasi utang tersebut kemudian telah disetujui oleh Rapat Umum Pemegang Saham Luar Biasa PT BFI, termasuk persetujuan dari PT APT dan PT OM selaku pemegang saham dari PT BFI. Selain itu, PT APT dan PT OM juga telah menandatangani Consent to Transfer (Persetujuan untuk Menjual) 7 Agustus 2000 dan Irrevocable Power of Attorney to Sell (Surat Kuasa untuk menjual yang tidak dapat ditarik kembali) 7 Agustus 2000.

Consent of Transfer tersebut mengatur bahwa: "ia (PT APT dan PT OM) mengijinkan dan menyetujui pelaksanaan oleh PT Bunas Finance Indonesia Tbk atas hak-haknya berdasarkan Perjanjian Gadai Saham 1 Juni 1999". Kemudian, dalam Irrevocable Power of Attorney to Sell diatur: "Kami (PT APT dan PT OM)... dengan ini memberikan kuasa dan wewenang yang tidak dapat ditarik kembali kepada PT BFI (untuk selanjutnya disebut "Pemberi Kuasa"), dengan hak substitusi yang dapat diberikan pada setiap saat dan untuk memberikan hak substitusi lebih lanjut sepanjang diperlukan Pemberi Kuasa, pada setiap saat, dari waktu ke waktu, untuk menjual dan mengalihkan atau sebaliknya menyerahkan:

(a)Saham-saham yang digadaikan sesuai dengan Perjanjian Gadai;

(b) ...

Baik melalui bursa efek Indonesia atau melalui pelelangan umum atau penjualan pribadi atau di bawah tangan, dengan harga tersebut dan pada kondisi tersebut sebagaimana patut oleh Pemberi Kuasa kepada setiap pihak...". 8

PT BFI sebagai hasil upaya negoisasi dan restrukturisasi utang pada 11 Oktober 2000 mengajukan rencana perdamaian agar dapat disetujui para kreditur PT BFI, di mana rencana tersebut telah mendapat persetujuan dari para pemegang saham, termasuk PT APT dan PT OM. Kemudian pada 7 Desember 2000, PT BFI dan para kreditur PT BFI menandatangani Perjanjian Perdamaian yang kemudian disahkan oleh Pengadilan Niaga Jakarta Pusat No. 04/PKPU/2000/PN.Niaga.Jkt.Pst, 19 Desember 2000. ${ }^{9}$

PT APT dan PT OM sampai jangka waktu tertentu tetap belum dapat melunasi utangnya pada PT BFI yang dijamin oleh perjanjian gadai saham, sehingga sebagai pelaksana putusan perdamaian dalam rangka restrukturasi utangnya, PT BFI telah mengalihkan saham-saham yang digadaikan PT APT dan

8Ibid., hlm. 4.

I'Ibid., hlm. 6. 
PT OM kepada The Law Debenture Trust Corporation P.L.C (selanjutnya disebut “L.D.T”), berdasarkan Share Sale and Purchase Agreement 9 Februari 2001. Sahamsaham tersebut dialihkan kepada L.D.T dengan cara silang gadai saham di Bursa Efek Jakarta pada 11 Mei 2001 sebagaimana tercantum dalam surat pemberitahuan dari PT BFI kepada PT APT dan PT OM 11 Mei 2001.

Akan tetapi, pada 2003 PT APT dan PT OM mengajukan gugatan ke Pengadilan Negeri Jakarta Pusat, di mana PT APT mengajukan gugatan pada 28 Maret 2003 yang terdaftar nomor 123/Pdt.G/2003/PN.Jkt.Pst dan PT OM mengajukan gugatan 11 Desember 2003 yang terdaftar nomor 514/Pdt.G/2003/PN.Jkt.Pst. Gugatan tersebut diajukan atas dasar dugaan perbuatan melawan hukum yang dilakukan oleh PT BFI, yaitu tanpa sepengetahuan dan tanpa persetujuan PT APT dan PT OM, PT BFI menjual saham-saham milik PT APT dan PT OM yang ada di PT BFI.

Apabila dilihat dari amar putusan, dapat dilihat bahwa terdapat perbedaan putusan hakim dalam memutus perkara yang dituangkan dalam Putusan Mahkamah Agung Nomor 240 PK/Pdt/2006 dan Putusan Mahkamah Agung Nomor 115 PK/Pdt/2007 tersebut. Pada Putusan Mahkamah Agung Nomor 240 PK/Pdt/2006, Majelis Hakim mengabulkan gugatan PT APT dan menyatakan bahwa PT BFI telah melakukan perbuatan melawan hukum atas dilakukannya eksekusi gadai saham milik PT APT pada PT BFI. Sedangkan dalam Putusan Mahkamah Agung Nomor 115 PK/Pdt/2007, Majelis Hakim menolak gugatan PT OM, sehingga PT BFI tidak terbukti melakukan perbuatan melawan hukum atas dilakukannya eksekusi gadai saham PT OM pada PT BFI.

Kedua perkara tersebut dapat dilihat memiliki masalah dan substansi gugatan yang sama, yaitu adanya dugaan perbuatan melawan hukum yang dilakukan oleh PT BFI atas dieksekusinya objek gadai berupa saham. Yang membedakan kedua perkara tersebut adalah subyek penggugat, di mana dalam Putusan Mahkamah Agung Nomor 240 PK/Pdt/2006 penggugatnya adalah PT APT, sedangkan dalam Putusan Mahkamah Agung Nomor 115 PK/Pdt/2007 penggugatnya adalah PT OM.

Perbedaan dasar pertimbangan hukum dari Majelis Hakim yang menyebabkan adanya perbedaan amar putusan dalam Putusan Mahkamah Agung Nomor 240 PK/Pdt/2006 dan Putusan Mahkamah Agung Nomor 115 PK/Pdt/2007 pada pokoknya adalah sebagai berikut:

Pertama, pada Putusan MA No. 240 PK/Pdt/2006, Majelis Hakim berpendapat bahwa perjanjian gadai saham berakhir pada 1 Desember 2000, bukan 1 Desember 2001. Majelis Hakim berpendapat bahwa pemberitahuan perpanjangan jangka waktu gadai saham yang dilakukan oleh PT BFI merupakan permintaan perpanjangan secara sepihak karena 
tidak pernah disetujui oleh PT APT sehingga tidak mengikat. Sedangkan pada Putusan MA No. 115 PK/Pdt/2007, Majelis Hakim berpendapat bahwa perpanjangan waktu gadai tidak memerlukan persetujuan PT OM selaku pemberi gadai, melainkan dapat dilakukan hanya dengan pemberitahuan oleh pemegang gadai kepada penerima gadai. Hal tersebut berdasarkan ketentuan butir 4.2. dari Perjanjian Gadai Saham tersebut yang berbunyi: "Perjanjian gadai ini tunduk pada pengakhiran sebelum berakhirnya jangka waktunya atau suatu perpanjangan jangka waktu yang dengan ini diadakan atas pilihan dari Penerima Gadai pada setiap saat setelah disampaikannya pemberitahuan kepada Pemberi Gadai".

Kedua, pada Putusan MA No. $240 \mathrm{PK} / \mathrm{Pdt} / 2006$, Majelis Hakim berpendapat bahwa hak untuk melakukan eksekusi gadai ada pada pihak pemegang gadai selama perjanjian gadai itu masih berlaku, sehingga dengan berakhirnya masa berlaku perpanjangan gadai dalam perkara tersebut, maka hak untuk mengeksekusi demi hukum berakhir juga. Sedangkan pada Putusan MA No. 115 PK/Pdt/2007, Majelis Hakim berpendapat bahwa perjanjian gadai saham akan berlaku terus dengan sistem diperpanjangan selama utang belum lunas.

Ketiga, Majelis Hakim dalam Putusan MA No. 240 PK/Pdt/2006 berpendapat bahwa eksekusi gadai saham tidak dapat dilakukan dengan penjualan di bawah tangan karena bertentangan dengan ketentuan Pasal 1155 KUHPerdata yang mengatur bahwa eksekusi barang gadai wajib dilakukan dengan dijual di muka umum atau dengan cara lelang, agar debitur tidak dirugikan. Sedangkan Majelis Hakim dalam Putusan MA No. 115 PK/Pdt/2007 berpendapat bahwa ketentuan mengenai eksekusi barang gadai wajib dilakukan dengan dijual di muka umum atau dengan cara lelang dapat disimpangi. Hal tersebut berdasarkan kalimat awal dari Pasal 1155 KUHPerdata yang berbunyi: "Apabila oleh para pihak tidak telah diperjanjikan lain...".

Keempat, Majelis Hakim dalam Putusan MA No. 240 PK/Pdt/2006 berpendapat bahwa rangkaian perbuatan PT BFI yang menjual sahamsaham APT kepada L.D.T serta menjadikannya sebagai sumber pembayaran urang-utangnya kepada para kreditornya meskipun utangutang tersebut tidak dijamin oleh gadai saham PT APT adalah merupakan perbuatan melawan hukum. Sedangkan Majelis Hakim dalam Putusan MA No. 115 PK/Pdt/2007 berpendapat bahwa Agenda Rapat Umum Pemegang Saham Luar Biasa (RUPSLB) 27 Januari adalah mengenai persetujuan pemegang saham PT OM atas restrukturisasi seluruh utang perseroan PT OM kepada kreditur termasuk utang obligasi. Oleh karena itu, dapat disimpulkan bahwa penjualan saham PT OM yang digadaikan adalah untuk menghapuskan piutang PT OM atas utang Ongko Group yang dijamin oleh PT OM karena telah mendapat persetujuan dalam RUPSLB dibuktikan dengan ditandatanganinya Consent to Transfer (Persetujuan untuk Menjual) 7 Agustus 2000 dan Irrevocable Power of 
Attorney to Sell (Surat Kuasa untuk menjual yang tidak dapat ditarik kembali) 7 Agustus 2000.

\section{Perlindungan Hukum Terhadap Hak Pemegang Jaminan Gadai Saham}

Sebelum penulis menganalisis mengenai perlindungan hukum yang diberikan terhadap hak pemegang jaminan saham dalam Putusan Mahkamah Agung Nomor 240 PK/Pdt/2006 dan Putusan Mahkamah Agung Nomor 115 PK/Pdt/2007, penulis akan terlebih dahulu mengkaji mengenai mekanisme penjaminan saham dengan gadai.

\section{Mekanisme Penjaminan dengan Gadai Saham}

Hal-hal yang perlu dilakukan dalam penjaminan dengan gadai saham adalah sebagai berikut: Pertama, adanya perjanjian gadai saham. Pasal 1151 KUHPerdata mengatur bahwa persetujuan gadai dibuktikan dengan segala alat yang diperbolehkan bagi pembuktian persetujuan pokoknya. Berdasarkan ketentuan Pasal 1151 KUHPerdata tersebut, gadai harus dibuat perjanjiannya. Gadai merupakan perjanjian accesoir (tambahan), sehingga perjanjian gadai tidak bisa berdiri sendiri dan tergantung pada perjanjian pokoknya. Perjanjian pokok dalam gadai adalah perjanjian pinjam meminjam uang dengan jaminan benda bergerak. Hal tersebut juga berlaku dalam gadai saham. Tidak seperti pada jaminan fidusia, Pasal 1151 KUHPerdata tidak mensyaratkan perjanjian gadai saham harus dalam bentuk akta notaris, sehingga perjanjian gadai saham dapat dibuat dalam bentuk akta di bawah tangan.

Perjanjian gadai saham mengatur mengenai hal-hal yang berkaitan dengan gadai dan saham sebagai objek gadai. Dalam perjanjian gadai saham ditentukan seberapa besar nilai saham yang dapat dijadikan jaminan gadai. Ketentuan tersebut dapat dibuat sesuai dengan kesepakatan para pihak. Selain itu, perjanjian gadai saham juga dapat memuat ketentuan-ketentuan seperti pelaksanaan eksekusi jaminan apabila pemberi gadai melakukan wanprestasi. ${ }^{10}$

Kedua, penyerahan barang gadai. Setelah perjanjian gadai saham dibuat dan disepakati, pemberi gadai menyerahkan benda yang menjadi objek gadai kepada pemegang gadai. Hal tersebut sesuai dengan ketentuan Pasal 1152 ayat (1) KUHPerdata, yaitu hak gadai atas benda-benda bergerak dan atas piutangpiutang bawa diletakkan dengan membawa barang gadainya di bawah kekuasaan si berpiutang atau seorang pihak ketiga, tentang siapa telah disetujui kedua belah pihak. Hak gadai akan menjadi tidak sah apabila objek gadai

10 Aulia Abdi, Pelaksanaan Gadai Saham Dalam Sistem Perdagangan Tanpa Warkat, Tesis, Magister Kenotariatan Fakultas Hukum Universitas Dipenogoro, Semarang, 2008, hlm. 38. 
tersebut dibiarkan tetap dalam kekuasaan pemberi gadai. ${ }^{11}$ Syarat penyerahan barang gadai tersebut disebut dengan istilah inbezitstelling.

Penyerahan barang-barang yang digadaikan kepada pemegang gadai bukan merupakan penyerahan yuridis, artinya bukan penyerahan yang mengakibatkan pemegang gadai menjadi pemilik. Oleh karena itu, pemegang gadai dengan dilakukannya penyerahan tersebut tetap hanya berkedudukan sebagai pemegang saja. ${ }^{12}$ Pada prakteknya selain penyerahan secara riil, terhadap saham sebagai objek gadai, terutama saham yang diperdagangkan dan tercatat di bursa biasanya saham hanya dititipkan kepada pihak ketiga, yaitu lembaga kustodian. Hal tersebut tidak melanggar ketentuan mengenai gadai, karena Pasal 1152 KUHPerdata membolehkan untuk menitipkan benda gadai kepada pihak ketiga sepanjang disepakati oleh pihak-pihak dalam gadai. ${ }^{13}$

Pihak ketiga tersebut mempunyai kedudukan hanya sebagai pemegang untuk kepentingan kreditur, tetapi dengan kedudukan mandiri. Dengan kata lain, pihak ketiga pemegang gadai tersebut bukanlah kuasa dari kreditur, sehingga ia tidak tunduk kepada perintah kreditur. Pihak ketiga tersebut berkewajiban untuk membantu agar maksud dari perjanjian gadai yang telah ada dapat terlaksana sesuai dengan apa yang telah disepakati dan selaku pihak ketiga yang membawa benda yang dijaminkan PT KSEI mempunyai tanggung jawab terhadap saham yang dititipkan kepadanya. ${ }^{14}$

Ketiga, pemberitahuan atau pengumuman. Syarat dilakukannya pemberitahuan tersebut terdapat dalam Pasal 1153 KUHPerdata yang mengatur bahwa hak gadai atas benda-benda bergerak yang tak bertubuh, kecuali suratsurat tunjuk atau surat-surat bawa, diletakkan dengan pemberitahuan perihal penggadaiannya, kepada orang terhadap siapa hak yang diagadaikan itu harus dilaksanakan. Dalam hal objek gadai merupakan saham, maka pemberitahuan itu ditujukan kepada perseroan yang mengeluarkan saham tersebut. Selain itu, Pasal 60 ayat (3) UUPT sebagai lex specialis mensyaratkan pencatatan dalam daftar saham dan daftar khusus. ${ }^{15}$ Pendaftaran tersebut bertujuan agar pihak lain yang berkepentingan dapat mengetahui status saham yang digadaikan tersebut.16 Apabila objek gadai merupakan saham yang terikat oleh sistem perdagangan

11 Pasal 1152 ayat (2) KUHPerdata, hlm. 297.

12 Mariam Darus Badrulzaman, Aneka Hukum Bisnis, Cetakan Pertama, Alumni, Bandung, 1994, hlm. 106.

13 Aulia Abdi, Op. Cit., hlm. 40-41.

14 Yuli Kurniawan dan Ninis Nugraheni, “Tinjauan Yuridis Lembaga Jaminan untuk Saham dalam Perdagangan Tanpa Warkat”, Perspektif Hukum, Vol. 12 No. 2, November 2012, hlm. 72.

15 Afani Widiati, et. al., "Analisis Yuridis Perlindungan Hukum atas Tindakan Gadai Saham yang Dilakukan oleh Manajer Investasi terhadap Efek Investor”, Dipenogoro Law Journal, Vol. 6 No. 2, 2017, hlm. 8.

16 Penjelasan Pasal 60 ayat (3) Undang-Undang Nomor 40 Tahun 2007 tentang Perseroan Terbatas. 
pasar modal, maka terdapat pihak ketiga yang ikut terlibat dalam transaksi gadai, yaitu lembaga pasar modal yang berwenang mengatur penyerahan saham. Setelah terjadinya kesepakatan gadai saham, pemegang saham selaku pemberi gadai memberitahukan kepada emiten atau Badan Administrasi Efek (BAE) dengan disertai pengajuan permohonan pemblokiran terhadap saham yang digadaikan dalam daftar pemegang saham dari emiten. ${ }^{17}$

Berdasarkan Peraturan Otoritas Jasa Keuangan Nomor 40/POJK.03/2017, saham yang telah terdaftar di bursa efek dapat dijadikan jaminan dengan beberapa persyaratan sebagai berikut:

a. Saham yang diagunkan tidak termasuk saham yang tidak mengalami transaksi dalam waktu 3 (tiga) bulan berturut-turut sebelum akad kredit atau pembiayaan ditandatangani; 18

b. Harga saham yang akan dijadikan agunan bukan merupakan saham dengan harga pasar di bawah nilai nominal pada saat akad kredit atau pembiayaan ditandatangani; 19

c. Nilai saham yang digunakan sebagai agunan tambahan kredit atau pembiayaan paling tinggi sebesar 50\% dari harga pasar atau kurs saham yang bersangkutan di bursa efek pada saat akad kredit atau pembiayaan ditandatangani. ${ }^{20}$

\section{Perlindungan Hukum Terhadap Hak Pemegang Jaminan Gadai Saham dalam Putusan Mahkamah Agung Nomor 240 PK/Pdt/2006 dan Putusan Mahkamah Agung Nomor 115 PK/Pdt/2007}

Penulis pada pembahasan sebelumnya telah menjelaskan bahwa pada Putusan MA No. 240 PK/Pdt/2006 dan Putusan MA No. 115 PK/Pdt/2007, terdapat perbedaan putusan yang dikeluarkan oleh Majelis Hakim meskipun substansi gugatannya sama, yang membedakannya adalah subyek penggugat. Terjadinya perbedaan putusan tersebut menyebabkan adanya ketidakpastian hukum terhadap hak PT BFI selaku tergugat atas kedua perkara tersebut dan sebagai pemegang gadai saham.

Majelis Hakim dalam Putusan MA No. 240 PK/Pdt/2006 memutus bahwa PT BFI telah melakukan perbuatan melawan hukum atas eksekusi yang dilakukan atas saham milik PT APT di PT BFI, sedangkan dalam Putusan MA No. 115 PK/Pdt/2007 Majelis Hakim berpendapat bahwa eksekusi yang dilakukan PT

17 Gatot Supramono, Transaksi Bisnis Saham \& Penyelesaian Sengketa Melalui Pengadilan, Cetakan Pertama, Kencana, Jakarta, 2014, hlm. 72.

18 Pasal 3 ayat (2) huruf a Peraturan Otoritas Jasa Keuangan Nomor 40/POJK.03/2017 tentang Kredit atau Pembiayaan kepada Perusahaan Efek dan Kredit atau Pembiayaan dengan Agunan Saham.

${ }_{19}$ Pasal 3 ayat (2) huruf b Peraturan Otoritas Jasa Keuangan Nomor 40/POJK.03/2017 tentang Kredit atau Pembiayaan kepada Perusahaan Efek dan Kredit atau Pembiayaan dengan Agunan Saham.

${ }^{20}$ Pasal 4 Peraturan Otoritas Jasa Keuangan Nomor 40/POJK.03/2017 tentang Kredit atau Pembiayaan kepada Perusahaan Efek dan Kredit atau Pembiayaan dengan Agunan Saham. 
BFI terhadap saham milik PT OM di PT BFI adalah sah demi hukum. Baik dalam Putusan MA No. 240 PK/Pdt/2006 dan Putusan MA No. 115 PK/Pdt/2007 menyatakan bahwa Perjanjian Gadai Saham antara PT APT dan PT OM dengan PT BFI merupakan perjanjian dengan suatu ketetapan waktu sebagaimana diatur dalam Pasal 1268 KUHPerdata ${ }^{21}$ Majelis Hakim berpendapat bahwa perjanjian dengan ketetapan waktu bersifat memutuskan ataupun mengakhiri daya kerja suatu perjanjian in casu jangka waktu perjanjian gadai secara pasti ditentukan berakhir. Oleh karena itu, barang gadai hanya terikat sebagai jaminan utang sampai dengan waktu jatuh tempo tersebut dan selama itu pemegang gadai berhak menjual barang gadai tersebut di muka umum. Dengan kata lain, Majelis Hakim berpendapat bahwa pemegang gadai tidak diperkenankan mengeksekusi barang-barang gadai pada saat gadai saham telah berakhir meskipun utang belum dibayar lunas oleh pemberi gadai.

Apabila Perjanjian Gadai Saham hanya diartikan sebagai perjanjian dengan ketetapan waktu, maka akan merugikan pemegang gadai. Pemegang gadai selaku kreditur akan dirugikan karena tidak mendapatkan kepastian hukum dalam pengembalian piutangnya dalam hal pemberi gadai melakukan wanprestasi atau tidak beritikad baik dalam pelaksanaan prestasinya. Seorang debitur yang melakukan perjanjian kredit dengan jaminan gadai diwajibkan mengembalikan atau membayar pinjamannya tepat pada waktunya sampai dengan tanggal jatuh tempo. Apabila sampai dengan tanggal jatuh tempo debitur tidak bisa melunasi pinjamannya tersebut maka debitur dapat dikatakan telah melakukan wanprestasi.

PT APT dan PT OM dalam kasus ini telah melakukan wanprestasi berupa belum dilunasinya utang atau tagihan sampai pada waktu yang telah ditentukan. Hal tersebut dibuktikan baik dalam Putusan MA No. 240 PK/Pdt/2006 maupun Putusan MA No. 115 PK/Pdt/2007 PT APT dan PT OM tidak melakukan bantahan atas dalil utang yang belum dilunasi kepada PT BFI. Berdasarkan ketentuan Pasal 1155 ayat (1) KUHPerdata, apabila jangka waktu Perjanjian Gadai Saham telah dilampaui dan pemberi gadai belum melunasi utangnya atau melakukan wanprestasi, maka pemegang gadai memiliki hak untuk melakukan eksekusi gadai atas saham-saham yang dijaminkan tersebut. Sejalan dengan ketentuan Pasal 1155 ayat (1) KUHPerdata tersebut, Yahya Harahap berpendapat bahwa apabila lampau waktu dikaitkan dengan perjanjian, lampau waktu tadi

${ }^{21}$ Pasal 1268 KUHPerdata berbunyi, "Suatu ketetapan waktu tidak menangguhkan perikatan, melainkan hanya menangguhkan pelaksanaannya". 
akan menghasilkan pengertian membebaskan seseorang dari suatu kewajiban atau bisa juga memberi hak kepada seseorang untuk memperoleh suatu hak. ${ }^{22}$

Oleh karena PT APT dan PT OM belum melunasi utangnya sampai jangka waktu yang ditentukan, maka berdasarkan ketentuan Pasal 1155 ayat (1) KUHPerdata tersebut, PT BFI memiliki hak untuk melakukan eksekusi terhadap saham-saham yang dijaminkan oleh PT APT dan PT OM tersebut. PT BFI atas dasar Consent to Tranfer 7 Agustus 2000 dan Irrevocable Power of Attorney to Sell 7 Agustus 2000, mengalihkan saham-saham yang digadaikan PT APT dan PT OM tersebut dengan penjualan di bawah tangan kepada L.D.T sesuai share sale and purchase agreement 9 Februari 2001.

Pengalihan saham dengan penjualan di bawah tangan tersebut dibenarkan oleh Majelis Hakim dalam Putusan MA No. 115 PK/Pdt/2007 yang dalam pertimbangannya menyatakan bahwa Pasal 1155 KUHPerdata tentang tata cara eksekusi barang gadai apabila pemberi gadai wanprestasi setelah lewatnya jangka waktu gadai yang pada umumnya dengan menjual di muka umum atau lelang dapat disimpangi berdasarkan kalimat awal dari Pasal 1155 KUHPerdata yang berbunyi: "Apabila oleh para pihak tidak diperjanjikan lain...".

Oleh karena itu, penulis berpendapat bahwa dengan adanya perbedaan Putusan MA No. 240 PK/Pdt/2006 dan Putusan MA No. 115 PK/Pdt/2007 mengenai keabsahan eksekusi gadai saham yang dilakukan oleh PT BFI mengakibatkan tidak terlindunginya hak PT BFI sebagai kreditur sekaligus pemegang gadai saham. Hal tersebut dikarenakan tidak ada kepastian hukum terkait pengembalian piutang dalam hal ini sampai jangka waktu yang ditentukan debitur selaku pemberi gadai belum melunasi utangnya. Akibat terjadinya dua putusan berbeda dari Majelis Hakim tersebut dalam kasus yang substansinya sama tersebut, bahkan Bursa Efek Jakarta pada waktu itu memutuskan untuk menghentikan perdagangan (suspend) PT BFI sejak 20 September 2007 untuk sementara waktu.

Sebagai perbandingan, penulis akan menjelaskan putusan hakim dalam perkara lain terkait dengan gadai saham. Dalam perkara antara Beckett PT E. LTD., sebagai penggugat melawan Deutsche Bank Aktiengesellschaft, dkk sebagai tergugat yang telah diputus oleh Mahkamah Agung dengan putusan 23 September 2010 No. 1130 K.Pdt/2010, Hakim dalam pertimbangan hukumnya membenarkan putusan Pengadilan Tinggi Jakarta 10 Desember 2009 No. 475/Pdt/2009 yang menguatkan putusan Pengadilan Negeri Jakarta Selatan 8 April 2009 No. 649/Pdt.G/2008/PN.Jkt.Sel yang menolak gugatan penggugat seluruhnya. Majelis Hakim menilai keberatan penggugat tidak dapat dibenarkan

22 Yahya Harahap, Segi-Segi Hukum Perjanjian, Cetakan Kedua, Alumni, Bandung, 1986, hlm. 166. 
karena judex facti sudah tepat dan benar serta tidak salah menerapkan hukum. Majelis Hakim berpendapat bahwa eksekusi di bawah tangan yang dilakukan Deutsche Bank sudah tepat karena dalam Pasal 5 a Share Pledge Agreement telah disebutkan bahwa Deutsche Bank selaku kreditur berhak menjual saham yang digadaikan di muka umum atau secara tertutup atau di bawah tangan sepanjang tidak bertentangan dengan undang-undang, apabila debitur wanprestasi. ${ }^{23}$

Berdasarkan putusan hakim terhadap perkara mengenai gadai saham yang telah dijabarkan oleh penulis di atas, dapat dilihat bahwa masih terdapat multitafsir atau perbedaan pendapat hakim khususnya mengenai pelaksanaan eksekusi gadai saham. Hal tersebut dikarenakan sampai saat ini mekanisme gadai saham masih mengacu pada ketentuan yang diatur dalam KUHPerdata yang mengatur gadai secara umum. Belum ada peraturan perundang-undangan maupun peraturan Otoritas Jasa Keuangan yang mengatur secara khusus mengenai tata cara pelaksanaan gadai saham. Multitafsir tersebut terutama lebih sering terjadi terhadap ketentuan Pasal 1155 KUHPerdata yang berbunyi:

“Apabila oleh para pihak tidak telah diperjanjikan lain, maka si berpiutang adalah berhak jika si berutang atau si pemberi gadai bercedera janji setelah tenggang waktu yang ditentukan lampau, atau jika tidak telah ditentukan suatu tenggang waktu, setelah dilakukannya suatu peringatan untuk membayar, menyuruh menjual barang gadainya di muka umum..."

Klausul "Apabila oleh para pihak tidak telah diperjanjikan lain" tersebut sering menimbulkan multitafsir, baik antara akademisi maupun hakim, yaitu apakah para pihak dalam perjanjian gadai dapat memuat ketentuan untuk menjual di bawah tangan apabila debitur wanprestasi atau dengan diperjanjikan lain maka para pihak dalam perjanjian dapat memuat ketentuan untuk dapat melakukan penjualan langsung melalui lelang tanpa bantuan pengadilan.

Dengan demikian, berdasarkan analisis yang telah penulis sampaikan dalam bab ini dapat dilihat bahwa sampai saat ini belum ada persamaan penafsiran mengenai pelaksanaan eksekusi gadai saham di Indonesia. Hal tersebut dikarenakan baik KUHPerdata maupun Undang-Undang Perseroan Terbatas serta peraturan terkait lainnya belum mengatur secara komprehensif mengenai pelaksanaan gadai saham, sehingga terjadinya multitafsir dan menimbulkan permasalahan hukum. Oleh karena itu, pemerintah perlu membentuk suatu peraturan yang mengatur secara khusus mengenai pelaksanaan gadai saham,

${ }^{23}$ Julianto Putra Hasudungan Sitompul, et. al., “Analisis Perjanjian Utang Piutang dengan Jaminan Gadai Saham pada Kasus Deutsche Bank Aktiengesellschaft Melawan Beckett, PTE. LTD”, Dipenogoro Law Journal, Vol. 5 No. 3, 2016, hlm. 16. 
terutama tata cara eksekusi gadai saham, sehingga tidak lagi terjadi ketidakpastian hukum dan memberikan perlindungan hukum kepada para pihak.

\section{Penutup}

Berdasarkan pembahasan di atas, maka dapat disimpulkan bahwa yang menjadi dasar pertimbangan hukum Hakim dalam memutus perkara ini antara lain sebagai berikut. Pertama, Majelis Hakim dalam Putusan MA No. 240 PK/Pdt/2006 berpendapat perpanjangan jangka waktu gadai dilakukan dengan persetujuan, sedangkan dalam Putusan MA No. 115 PK/Pdt/2007, perpanjangan jangka waktu gadai dilakukan dengan pemberitahuan. Kedua, Majelis Hakim dalam Putusan MA No. 240 PK/Pdt/2006 berpendapat dengan berakhirnya masa berlaku perpanjangan gadai dalam perkara tersebut, maka hak untuk mengeksekusi demi hukum berakhir juga, sedangkan dalam Putusan MA No. 115 PK/Pdt/2007, Majelis Hakim berpendapat bahwa perjanjian gadai saham akan berlaku terus dengan sistem diperpanjangan selama utang belum luna. Ketiga, dalam Putusan MA No. 240 PK/Pdt/2006 Majelis Hakim berpendapat bahwa eksekusi gadai tidak dapat dilakukan dengan penjualan di bawah tangan, sedangkan dalam Putusan MA No. 115 PK/Pdt/2006, eksekusi gadai dapat dilakukan dengan penjualan di bawah tangan.

Akibat adanya perbedaan Putusan MA No. 240 PK/Pdt/2006 dan Putusan MA No. 115 PK/Pdt/2007 yang substansi kasusnya sama, maka hak PT BFI selaku pemegang gadai menjadi tidak terlindungi karena tidak ada kepastian hukum terkait pengembalian piutang dalam hal ini sampai jangka waktu yang ditentukan PT APT dan PT OM belum melunasi utangnya, sehingga menimbulkan berbagai kerugian bagi PT BFI. Selain itu, masih terdapat perbedaan pendapat hakim mengenai pelaksanaan gadai saham jika dilihat dari beberapa putusan pengadilan sehingga menimbulkan permasalahan hukum. Oleh karena itu, perlu dibuatnya peraturan yang lebih khusus mengatur mengenai gadai saham, sehingga dapat memberikan kepastian hukum dan menjamin perlindungan hak, baik bagi pemberi gadai maupun pemegang gadai.

\section{Daftar Pustaka}

\section{Buku}

Badrulzaman, Mariam Darus, Aneka Hukum Bisnis, Cetakan Pertama, Alumni, Bandung, 1994.

Harahap, Yahya, Segi-Segi Hukum Perjanjian, Cetakan Kedua, Alumni, Bandung, 1986.

Supramono, Gatot, Transaksi Bisnis Saham \& Penyelesaian Sengketa Melalui Pengadilan, Cetakan Pertama, Kencana, Jakarta, 2014. 
Usman, Rachmadi, Hukum Jaminan Keperdataan, Cetakan Pertama, Sinar Grafika, Jakarta, 2008

\section{Jurnal}

Kurniawan, Yuli dan Ninis Nugraheni, "Tinjauan Yuridis Lembaga Jaminan untuk Saham dalam Perdagangan Tanpa Warkat", Perspektif Hukum, Vol. 12 No. 2, November 2012.

Sitompul, Julianto Putra Hasudungan, et. al., “Analisis Perjanjian Utang Piutang dengan Jaminan Gadai Saham pada Kasus Deutsche Bank Aktiengesellschaft Melawan Beckett, PTE. LTD", Dipenogoro Law Journal, Vol. 5 No. 3, 2016.

Widiati, Afani, et. al., "Analisis Yuridis Perlindungan Hukum atas Tindakan Gadai Saham yang Dilakukan oleh Manajer Investasi terhadap Efek Investor", Dipenogoro Law Journal, Vol. 6 No. 2, 2017.

\section{Hasil Penelitian/Tugas Akhir}

Abdi, Aulia, Pelaksanaan Gadai Saham Dalam Sistem Perdagangan Tanpa Warkat, Tesis, Magister Kenotariatan Fakultas Hukum Universitas Dipenogoro, Semarang, 2008.

\section{Peraturan Perundang-Undangan}

Kitab Undang-Undang Hukum Perdata. Diterjemahkan oleh R. Subekti dan R. Tjitrosudibio, Cetakan Keempat Puluh Satu, Balai Pustaka, Jakarta, 2014.

Undang-Undang Nomor 40 Tahun 2007 tentang Perseroan Terbatas, Lembara Negara Republik Indonesia Nomor 106 Tahun 2007, Tambahan Lembaran Negara RI Nomor 4756.

Peraturan Otoritas Jasa Keuangan Nomor 40/POJK.03/2017 tentang Kredit atau Pembiayaan kepada Perusahaan Efek dan Kredit atau Pembiayaan dengan Agunan Saham, Lembaran Negara Republik Indonesia Nomor 146 Tahun 2017, Tambahan Lembaran Negara RI Nomor 6089.

\section{Putusan Pengadilan}

PT Aryaputra Teguharta v. PT BFI Finance Indonesia Tbk., dkk, Putusan Mahkamah Agung Republik Indonesia pada tingkat Peninjauan Kembali Nomor 240 $\mathrm{PK} / \mathrm{Pdt} / 2006$.

PT Ongko Multicorpora v. PT BFI Finance Indonesia Tbk., dkk, Putusan Mahkamah Agung Republik Indonesia pada tingkat Peninjauan Kembali Nomor 115 PK/Pdt/2007. 